\title{
ASPEK HUKUM KESELAMATAN DAN KESEHATAN KERJA (K3) BAGI TENAGA MEDIS DAN KESEHATAN DI MASA PANDEMI
}

\author{
(Legal Aspects of Occupational Safety and Health for Medical \\ and Health Workers During the Pandemic)
}

\author{
M Nur Sholikin \\ Pusat Studi Hukum dan Kebijakan Indonesia (PSHK) \\ Puri Imperium Office Plaza G-9, Kuningan, Jakarta Selatan 12980 \\ e-mail: nur.sholikin@pshk.or.id \\ Herawati \\ Anggota IDI Tangerang Selatan \\ Pondok Safari Indah, Jurangmangu Barat, Tangerang Selatan 15223 \\ e-mail: herateaku@gmail.com
}

\begin{abstract}
Abstrak
Sejumlah data menunjukkan kejadian tenaga medis dan tenaga kesehatan yang terkena penyakit akibat kerja karena COVID-19. Sejumlah potensi bahaya bagi pekerja di rumah sakit menempatkan pada risiko tinggi keselamatan kerja saat pandemi ini. Bagaimana peraturan perundang-undangan mengatur perlindungan kerja bagi tenaga medis dan kesehatan terutama pada masa pandemi? Untuk menjawab permasalahan tersebut dilakukan melalui identifikasi dan analisis terhadap peraturan perundang-undangan terkait. Terdapat sejumlah peraturan perundang-undangan telah mengatur aspek keselamatan dan kesehatan kerja di rumah sakit. Bahkan terkait dengan jaminan kesehatan kerja terdapat juga pengaturan program pencegahan dan pengendalian infeksi. Sementara itu dalam hal perlindungan jaminan keselamatan dan kesehatan kerja pada masa pandemi, masih terdapat beberapa kelemahan dalam pengaturan yang menimbulkan ketidakpastian pemenuhan jaminan perlindungan tersebut. Untuk mengoptimalkan perlindungan tenaga medis dan tenaga ksehatan pada saat pandemi pemerintah perlu melakukan pengawasan dan pemberian dukungan bagi pelaksanaan keselamatan dan kesehatan kerja dan pelaksanaan program pencegahan dan pengendalian infeksi. Selain itu, diperlukan juga pengaturan teknis pemberian penghargaan, kompensasi dan pendayagunaan tenaga kesehatan dengan memastikan pemenuhan hak tersebut bagi tenaga kesehatan yang mempunyai tugas penanganan COVID-19 dan bagi pekerja yang terkena penyakit akibat kerja karena COVID-19.
\end{abstract}

Kata kunci: Keselamatan dan Kesehatan Kerja (K3), tenaga kesehatan, pandemi COVID-19.

\begin{abstract}
A number of data shows the incidence of medical workers and health workers affected by occupational diseases due to COVID-19. There are a number of potential hazards for hospital workers caused by various factors. How do laws and regulations regulate protection for medis and health workers, especially during a pandemic? This research done through identification and analysis of the relevant laws and regulations. There are a number of laws and regulations that have regulate on occupational safety and health in hospitals. Meanwhile in the case of during the pandemic, there are still some weaknesses in the regulation that cause uncertainty in the fulfillment of the protection. The government needs to conduct supervision and provide support for the implementation. Compensating health workers are also needed to ensure the fulfillment of rights for health workers who have task of handling COVID-19 and affected by occupational illness due to COVID-19.
\end{abstract}

Keywords: Occupational safety and health, health workers, COVID-19 pandemi. 


\section{A. Pendahuluan}

Pada 31 Desember 2019, World Health Organization (WHO) melaporkan kasus pneumonia yang belum diketahui etiologinya di Kota Wuhan, Provinsi Hubei, Cina. Selanjutnya, pada 2 Januari 2020 Cina mengidentifikasi kasus tersebut sebagai jenis coronavirus (novel coronavirus, 2019-nCoV). ${ }^{1}$ Corona Virus (COVID-19) ini merupakan keluarga besar virus yang menyebabkan penyakit mulai dari gejala ringan sampai berat. Tanda dan gejala umum infeksi COVID-19 antara lain gejala gangguan pernapasan akut seperti demam, batuk dan sesak napas. Kasus COVID-19 yang berat dapat menyebabkan pneumonia, sindrom pernapasan akut, gagal ginjal dan bahkan kematian. ${ }^{2}$

COVID-19 yang pertama kali ditemukan di Wuhan, dengan cepat menyebar ke negara lain. Kasus pertama di luar Cina ditemukan di Thailand. Pada 13 Januari 2020, Thailand melaporkan kasus konfirmasi pertama COVID-19. Pada 16 Januari 2020, Jepang melaporkan kasus warga Tiongkok positif COVID-19 saat dirawat di rumah sakit. Thailand melaporkan kasus positif COVID-19 kedua pada 17 Januari 2020. Kasus ini terjadi pada perempuan usia 74 tahun yang mendarat di Bangkok usai dari Wuhan. Selanjutnya pada 20 Januari 2020, Korea Selatan melaporkan satu kasus konfirmasi positif COVID-19. ${ }^{3}$ Setelah itu dengan cepat kasus COVID-19 ditemukan di Perancis, Uni Emirat Arab, Australia dan silih berganti berbagai negara melaporkan kasus ini. ${ }^{4}$ Pada 11 Maret 2020, WHO menetapkan COVID-19 sebagai pandemi.

Kasus pertama di Indonesia diumumkan pada 2 Maret 2020 oleh Presiden Joko Widodo. Hingga kini kasus positif COVID-19 di Indonesia terus bertambah. Data di situs Kementerian Kesehatan pada 13 Juni 2020 menunjukkan jumlah kasus positif sebanyak 37.420 kasus, sebanyak 13.776 kasus positif yang sembuh dan 2.091 meninggal. ${ }^{5}$ Sementara itu, kasus positif COVID-19 di dunia telah mencapai 36.406, dengan 1.901.079 sembuh dan 328.227 meninggal. COVID-19 ini telah menyebar di 216 negara. Jumlah tersebut semakin bertambah.

Penyebaran COVID-19 semakin luas di berbagai negara dan dampak yang ditimbulkan sangat besar baik ada aspek kesehatan, sosial maupun ekonomi, Pembatasan aktifitas warga pun dilakukan. Untuk mempercepat penanganan terhadap COVID-19, Presiden membentuk gugus tugas percepatan penanganan COVID-19. Pembentukan gugus tugas tersebut dilakukan melalui penerbitan Keputusan Presiden Nomor 7 Tahun 2020 tentang Gugus Tugas Percepatan Penanganan Corona Virus Disease-2019 (COVID-19). Keppres ini kemudian direvisi dengan Keputusan Presiden Nomor 9 Tahun 2020 tentang Perubahan atas Keputusan Presiden Nomor 7 Tahun 2020 tentang Gugus Tugas Percepatan Penanganan Corona Virus Disease-2019 (COVID-19).

Penanganan COVID-19 menempatkan

$1 \quad$ Kementerian Kesehatan, Pedoman Kesiapsiagaan Menghadapi Infeksi Novel Coronavirus (2019-nCoV), Direktorat Jenderal Pencegahan dan pengendalian Penyakit, Januari 2020.

2 Kementerian Kesehatan, Pedoman Kesiapsiagaan Menghadapi Infeksi Novel Coronavirus (2019-nCoV), Direktorat Jenderal Pencegahan dan pengendalian Penyakit, Maret 2020

3 Amalia Zharina, Kronologi Virus Corona di China Dari Pasar hingga Korea Selatan, https://sains.kompas.com/ $\mathrm{read} / 2020 / 01 / 21 / 183300123 /$-kronologi-virus-corona-di-china-dari-pasar-hingga-korea-selatan?page=all, diakses pada 7 Oktober 2020.

4 Bima Baskara, Rangkaian Peristiwa Pertama COVID-19 dimuat dalam https://kompas.id/baca/riset/2020/04/18/ rangkaian-peristiwa-pertama-covid-19/ diakses tanggal 13 Juni 2020.

5 Kementerian Kesehatan, Situasi COVID-19, dimuat dalam https://www.kemkes.go.id/, diakses pada 14 Juni 2020. 
tenaga medis dan tenaga kesehatan ${ }^{6}$ menjadi unsur utama dalam menghadapi serangan virus ini. Selain itu, ketersediaan fasilitas pelayanan kesehatan dan peralatan medis menjadi faktor penting yang dapat menentukan keberhasilan penanganan COVID-19 ini. Di tengah keterbatasan fasilitas layanan dan peralatan medis, tenaga kesehatan memiliki risiko tinggi dalam menangani pasien COVID-19 ini. Ikatan Dokter Indonesia (IDI) pada 7 Juni 2020 menyebutkan sebanyak 32 Dokter meninggal akibat COVID-19.' Sedangkan jumlah perawat yang meninggal terpapar COVID-19 ini juga telah mencapai 20 kasus. $^{8}$

Penulis perlu menjelaskan terlebih dahulu bahwa berdasarkan peraturan perundangundangan dan putusan Mahkamah Konstitusi terdapat pembedaan antara tenaga medis. Undang-Undang Nomor 36 Tahun 2014 tentang Tenaga Kesehatan memberikan definisi bahwa tenaga kesehatan adalah setiap orang yang mengabdikan diri dalam bidang kesehatan serta memiliki pengetahuan dan/atau keterampilan melalui pendidikan di bidang kesehatan yang untuk jenis tertentu memerlukan kewenangan untuk melakukan upaya kesehatan. Pengertian ini memasukkan dokter, dokter gigi dan dokter spesialis sebagai tenaga kesehatan. Namun, definisi dikoreksi oleh Mahkamah Konstitusi melalui putusan pengujian undang-undang nomor 82/PUU-XIII/2015 dengan mengeluarkan dokter. dokter gigi dan dokter spesialis sebagai tenaga kesehatan. Penyebutan untuk ketiga profesi tersebut menjadi tenaga medis.

Masih tingginya kasus sebaran COVID-19, menempatkan tenaga kesehatan baik dokter, perawat maupun tenaga kesehatan lainnya pada risiko terpapar COVID-19 ini. Risiko ini bisa terjadi di fasilitas layanan kesehatan yang menjadi rujukan penanganan COVID-19 maupun pada fasilitas layanan kesehatan yang bukan merupakan rujukan penangana COVID-19. Fasilitas layanan kesehatan terutama rumah sakit merupakan jenis industri dengan karakteristik khusus diantaranya jumlah tenaga kerja yang banyak, penggunaan teknologi tinggi, frekuensi pekerjaan yang terus menerus, keleluasaan akses masyarakat atau bukan pekerja untuk masuk di rumah sakit. Karakteristik tersebut menunjukkan semakin kompleksnya mitigasi risiko pekerjaan pada tenaga kesehatan. Dimensi keselamatan dan kesehatan kerja (K3) rumah sakit tidak hanya terletak pada pekerja di rumah sakit saja, namun paparan risiko pekerjaan rumah sakit juga bisa menjangkau pada masyarakat dan lingkungan. Risikorisiko tersebut pada kondisi darurat seperti pandemi COVID-19 ini menunjukkan pentingnya penerapan K3 pada fasilitas layanan kesehatan terutama rumah sakit.

Hak pekerja atas K3 telah dijamin di dalam Undang-Undang Nomor 13 Tahun 2003 tentang

6 Terdapat perbedaan istilah antara tenaga medis dengan tenaga kesehatan paska putusan MK Nomor 82/PUU-XIII/2015 yang mengeluarkan dokter, dokter gigi, dokter spesialis dan dokter gigi spesialis dari definisi tenaga kesehatan yang diatur dalam UU No. 36 tahun 2014 tentang Tenaga Kesehatan. Namun dalam tulisan ini untuk memudahkan membaca menggunakan istilah tenaga medis dan tenaga kesehatan secara bergantian dan bersamaan dengan maksud yang sama yaitu merujuk pekerja yang bekerja di fasilitas layanan kesehatan dengan kategori tertentu sesuai yang diatur dalam masing-masing peraturan perundang-undangan yang dirujuk dalam tulisan ini.

7 Luthfia Ayu Azanella, 32 Dokter Meninggal Akibat COVID-19 Mayoritas Bertugas di RS Non Covid, dimuat dalam https:// www.kompas.com/tren/read/2020/06/07/151200365/32-dokter-meninggal-akibat-covid-19-mayoritas-bertugas-dirs-non-covid-19, diakses pada 14 Juni 2020.

8 Vitoriao Mantalean, PPNI: 20 Perawat di Indonesia Meninggal Dunia dalam Tugas Melayani Pasien COVID-19, dimuat dalam https://megapolitan.kompas.com/read/2020/05/19/05582081/ppni-20-perawat-di-indonesia-meninggaldunia-dalam-tugas-melayani-pasien, diakses pada 15 Juni 2020. 
Ketenagakerjaan (UU Ketenagakerjaan). Pasal 86 UU Ketenagakerjaan mengatur bahwa setiap pekerja/buruh mempunyai hak memperoleh perlindungan atas keselamatan dan kesehatan kerja. Upaya K3 ditujukan untuk memberikan jaminan keselamatan dan meningkatkan derajat kesehatan para pekerja/buruh dengan cara pencegahan kecelakaan dan penyakit akibat kerja, pengendalian bahaya di tempat kerja, promosi kesehatan, pengobatan, dan rehabilitasi. K3 memiliki peran, pertama, menciptakan lingkungan kerja yang selamat dengan melakukan penilaian secara kualitatif dan kuantitatif. Kedua, menciptakan kondisi yang sehat bagi karyawan, keluarga dan masyarakat sekitarnya melalui upaya promotif, preventif, kuratif dan rehabilitatif. ${ }^{9}$

Berkaitan dengan hal tersebut, tulisan ini mengkaji pengaturan jaminan $\mathrm{K} 3$ di rumah sakit yang memiliki karakteristik khusus pada lingkungan kerjanya dengan rumusan pertanyaan meliputi: Pertama, bagaimana konsepsi dan pegaturan K3 dalam hubungan ketenagakerjaan? Kedua, bagaimana kerangka hukum pengaturan K3 pada fasilitas layanan kesehatan? Ketiga, bagaimana jaminan perlindungan bagi tenaga medis dan tenaga kesehatan pada masa pandemi?

\section{B. Metode Penelitian}

Penulisan artikel ini menggunakan metode yuridis normatif dengan mengkaji berbagai literatur yang relevan dengan tema yang dikaji. Pengumpulan data dilakukan melalui studi pustaka untuk menemukan bahan hukum sekunder yang relevan yang bersumber dari peraturan perundang-undangan, literatur baik buku, artikel jurnal, artikel berita dari internet yang relevan dengan topik penulisan. Sejumlah peraturan yang menjadi fokus dalam penulisan artikel ini yaitu UU Ketenagakerjaan, Peraturan Menteri Kesehatan Nomor 66 Tahun 2016 tentang Keselamatan dan Kesehatan Kerja Rumah Sakit (Permenkes K3RS), dan Peraturan Menteri Kesehatan Nomor 27 Tahun 2017 tentang Pencegahan dan Pengendalian Infeksi (Permenkes PPI). Pendekatan yang dilakukan dalam penelitian ini adalah deskriptif preskriptif dengan memberikan gambaran dan analisis terhadap kerangka hukum perlindungan bagi tenaga medis dan kesehatan serta saran bagi optimalisasi implementasi peraturan perundang-undangan untuk mewujudkan efektifitas perlindungan tenaga medis dan kesehatan pada masa pandemi.

\section{Pembahasan}

1. Konsepsi dan Pengaturan K3 dalam Hubungan Ketenagakerjaan

K3 atau Occupational Safety and Health menurut ILO dan WHO didefinisikan sebagai upaya peningkatan dan pemelihataan pada derajat tertinggi kesejahteraaan fisik, mental dan sosial pekerja pada semua pekerjaan. ${ }^{10} \mathrm{~K} 3$ juga dapat didefinsikan sebagai pengetahuan antisipasi, pengenalan, evaluasi serta pengendalian bahaya yang timbul di dalam atau dari tenpat kerja yang dapat merusak kesehatan dan kesejahteraan pekerja dengan mempertimbangkan kemungkinan dampak pada masyarakat sekitar dan lingungkan umum. K3 merupakan komponen yang penting bagi perlindungan sosial pekerja terhadap dampak negatif pekerjaan, kecelakaan akibat kerja

9 Anita Dewi Prahastuti Sujoso, Dasar-dasar Keselamatand an Kesehatan Kerja, Jember: Jember University Press, 2012, hal. 2.

10 Intenational Labour Organzation, Occupational Safety and Health Policy Document, On The Road to a Safer and Healthier Culture at Work, March 2016, hal. 18-19. 
dan penyakit akibat kerja. Komponen ini akan meningkatkan kepuasan kerja dan memperkuat fungsi pasar tenaga kerja dan kualitas sumber daya manusia. Pada sisi lain, standar K3 yang buruk, kecelakaan kerja, kematian dan penyakit akibat kerja memberikan beban besar pada perekonomian nasional melalui pembayaran kompensasi sosial, biaya rumah sakit, pelatihan ulang dan pengantian pekerja serta kehilangan produktifitas. $^{11}$

Dokumen ILO lainnya menyebutkan bahwa setiap tahun ada lebih dari 250 juta kecelakaan di tempat kerja dan lebih dari 160 juta pekerja menjadi sakit karena bahaya di tempat kerja. Terdapat 1,2 juta pekerja meninggal akibat kecelakaan dan sakit di tempat kerja. ${ }^{12}$ Tingginya jumlah ini menunjukkan biaya manusia dan sosial dari produksi terlalu tinggi. Apabila dilihat dari aspek ekonomi dapat diperkirakan bahwa kerugian tahunan akibat kecelakaan kerja dan penyakit yang berhubungan dengan pekerjaan di beberapa negara dapat mencapai 4 persen dari produk nasional bruto (PNB). Biaya langsung dan tidak langsung dari dampak yang ditimbulkannya meliputi: ${ }^{13}$

a. Biaya medis;

b. Kehilangan hari kerja;

c. Mengurangi produksi;

d. Hilangnya kompensasi bagi pekerja;

e. Biaya waktu / uang dari pelatihan dan pelatihan ulang pekerja;

f. kerusakan dan perbaikan peralatan;

g. Rendahnya moral staf;

h. Publisitas buruk; i. Kehilangan kontrak karena kelalaian.

K3 memiliki tujuan meningkatkan dan memelihara derajat tertinggi kesejahteraan fisik, mental, dan sosial pekerja pada semua jenis pekerjaan, pencegahan keberadaan dan ketidakhadiran pekerja karena kondisi kesehatan yang disebabkan kondisi kerja yang tidak layak, melindungi pekerja pada tempat kerjanya terhadap risiko yang muncul dari faktor-faktor yang dapat merugikan kesehatan, penempatan dan pemeliharaan pekerja di lingkungan kerja yang sesuai dengan kondisi fisiologis dan psikologis pekerja dan untuk menciptakan kesesuaian antara pekerjaan dengan pekerja dan setiap pekerja dengan pekerjaannya. ${ }^{14}$ K3 berupaya untuk mewujudkan data tahan jasmani dan rohani atau fisik dan mental dalam lingkup ketenagakerjaan. Dengan pengelolaan K3 yang baik diharapkan tenaga kerja dapat melakukan pekerjaan dengan aman dan nyaman serta mencapai ketahanan fisik, daya kerja, dan tingkat kesehatan yang tinggi. ${ }^{15}$

Pengelolaan K3 memiliki dampak langsung terhadap kondisi pekerja, pekerjaan dan lingkungan. Selain itu, pengelolaan K3 juga akan berdampak secara tidak langsung pada perekonomian diantaranya menurunkan produkifitas dan menambah beban pengeluaran terkait dengan biaya kesehatan. Jangkauan pengaruh K3 tidak hanya terletak pada internal perusahaan dalam lingkup hubungan kerja semata, namun juga memiliki jangkauan keluar dengan dampaknya terhadap lingkungan dan masyarakat. Salah satunya terkait dengan

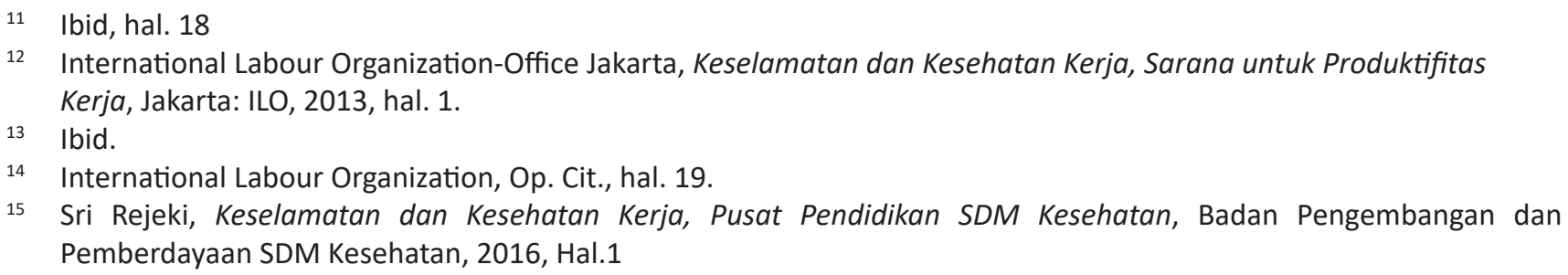


limbah yang dihasilkan dari kegiatan industri atau perusahaan. Beberapa kasus menunjukkan pencemaran sungai yang diakibatkan oleh kegiatan industri. Sebagai contoh di Kabupaten Tangerang terdapat empat sungai yang tercemar akibat limbah industri. ${ }^{16}$ Oleh karena itu, kebijakan ketenagakerjaan menempatkan jaminan K3 menjadi faktor yang penting dalam menjalankan hubungan kerja. Jaminan pelaksanaan K3 merupakan hak normatif bagi setiap pekerja yaitu hak yang pemenuhannya dijamin dalam peraturan perundang-undangan.

Pengaturan K3 dalam sistem perundangundangan di Indonesia telah dimulai sejak Undang-Undang Nomor 1 Tahun 1970 tentang Keselamatan Kerja (UU Keselamatan Kerja). Undang-undang tersebut menggantikan peraturan tentang keselamatan kerja peninggalan Belanda yaitu Veiligheidsreglement Tahun 1910 (Stbl. No. 406). Undang-Undang Nomor 1 Tahun 1970 dibentuk untuk mengatur keselamatan kerja yang sesuai dengan perkembangan masyarakat, industrialisasi dan teknologi. Undang-undang ini juga mengakui bahwa tenaga kerja berhak mendapatkan perlindungan atas keselamatannya dalam melakukan pekerjaan untuk kesejahteraan hidup dan meningkatkan produksi serta produktifitas nasional. Selanjutnya, K3 sebagai hak dasar pekerja juga ditegaskan pengaturannya dalam Undang-Undang Nomor 13 Tahun 2003 tentang Ketenagakerjaan (UU Ketenagakerjaan). Dalam undang-undang yang menjadi dasar pengaturan hubungan ketenagakerjaan saat ini, K3 ditegaskan sebagai hak pekerja dan pada sisi lain menjadi kewajiban pengusaha. Pasal 86 ayat (1) dan ayat (2) mengatur:
(1) Setap pekerja/ Buruh mempunyai hak untuk mendapatkan perlindungan atas:

a. keselamatan dan kesehatan kerja;

b. moral dan kesusilaan; dan

c. perlakuan yang sesuai dengan harkat dan martabat manusia serta nilai-nilai agama.

(2) Untuk melindungi keselamatan pekerja/ buruh guna mewujudkan produktivitas kerja yang optimal diselenggarakan upaya keselamatan dan kesehatan kerja.

Pasal 86 tersebut menegaskan tiga hal terkait dengan K3 yaitu: (i) K3 sebagai hak pekerja, (iii) K3 sebagai upaya untuk melindungi keselamatan pekerja/buruh dan (iii) K3 sebagai upaya mewujudkan prodiktivitas kerja. Bagian penjelasan Pasal 86 ayat (2) menerangkan bahwa upaya keselamatan dan kesehatan kerja dimaksudkan untuk memberikan jaminan keselamatan dan meningkatkan derajat kesehatan para pekerja/buruh dengan cara pencegahan kecelakaan dan penyakit akibat kerja, pengendalian bahaya di tempat kerja, promosi kesehatan, pengobatan, dan rehabilitasi. Selanjutnya, pengaturan tentang K3 sebagai kewajiban perusahaan juga diatur dalam UU Ketenagakerjaan. Pasal 87 ayat (1) UU Ketenagakerjaan mengatur sebagai berikut:

Setiap perusahaan wajib menerapkan sistem manajemen keselamatan dan kesehatan kerja yang terintegrasi dengan sistem manajemen perusahaan

Ketentuan tersebut mewajibkan pengaturan tentang K3 menjadi satu dengan sistem manajemen perusahaan. Hal ini menunjukkan bahwa K3 merupakan bagian integral dari proses manajemen perusahaan. Terjadinya kecelakaan

16 Joniansyah, Ini Empat Sungai di Kabupaten Tangerang Tercemar Limbah Industri, https://metro.tempo.co/ read/1187764/ini-4-sungai-di-kabupaten-tangerang-tercemar-limbah-industri/full\&view=ok, diakses pada 7 Oktober 2020. 
kerja bukan merupakan risiko individu atau personal risk dimana perusahaan dapat lepas tanggung jawabanya, akan tetapi kecelakaan kerja merupakan tanggung jawab perusahaan/ pengusaha atau employers liability sehingga pengaturannya harus terintegrasi dengan sistem manajemen perusahaan.

Khusus terkait dengan kesehatan kerja, pengaturannya juga terdapat dalam Undang-Undang Nomor 36 Tahun 2009 tentang Kesehatan (UU Kesehatan). Terdapat satu bab yang khusus mengatur tentang kesehatan kerja yaitu pada Pasal 164 sampai dengan Pasal 166. Pengaturannya antara lain tentang:

a. upaya kesehatan kerja meliputi pekerja di sektor formal dan informal;

b. upaya kesehatan kerja juga berlaku di lingkungan tempat kerja bagi setiap orang selain pekerja;

c. pemerintah menetapkan standar kesehatan kerja;

d. pengelola tempat kerja wajib menaati standar kesehatan dan menjamin lingkungan kerja yang sehat serta bertanggungjawab atas terjadinya kecelakaan kerja;

e. pengelola tempat kerja wajib melakukan segala bentuk upaya kesehatan melalui upaya pencegahan, peningkatan, pengobatan dan pemulihan bagi tenaga kerja;

f. pekerja wajib menciptakan dan menjaga kesehatan tempat kerja yang sehat dan menaati peraturan yang berlaku di tempat kerja;

g. dalam seleksi calon pegawai, hasil pemeriksaan keseharan secara fisik dan mental digunakan sebagai bahan pertimbangan dalam mengambil keputusan;

h. majikan atau pengusaha wajib menjamin kesehatan pekerja dan wajib menanggung seluruh biaya pemeliharaan kesehatan pekerja;

i. majikan atau pengusaha menanggung biaya atas gangguan kesehatan akibat kerja yang diderita oleh pekerja; dan

j. pemerintah memberikan dorongan dan bantuan untuk perlindungan pekerja dalam upaya menjamin kesehatan pekerja, biaya pemeliharaan kesehatan pekerja dan biaya atas gangguan kesehatan akibat kerja.

Ketentuan terkait kesehatan kerja dalam UU Kesehatan tersebut secara jelas mengatur pekerja dan pemberi kerja/perusahaan/ majikan dalam upaya menjaga dan menangani kesehatan di tempat kerja. Hal penting lainnya di dalam pengaturan UU Kesehatan Kerja adalah penegasan bahwa upaya kesehatan kerja tidak hanya berlaku pada sektor formal, tetapi juga berlaku pada hubungan kerja sektor informal.

Ketentuan di dalam UU Keselamatan Kerja, UU Ketenagakerjaan dan UU Kesehatan telah menjadi dasar hukum penerapan K3 dalam setiap hubungan kerja. Selain ketiga undangundang tersebut, terdapat sejumlah pengaturan pada jenis peraturan perundang-undangan di bawah undang-undang yang mengatur lebih teknis pelaksanaan K3. Peraturan perundangundangan tersebut diantaranya:

a. Peraturan Pemerintah Nomor 88 Tahun 2019 tentang Kesehatan Kerja;

b. Peraturan Pemerintah Nomor 50 Tahun 2012 tentang Sistem Manajemen Keselamatan dan Kesehatan Kerja;

c. Peraturan Presiden Nomor 7 Tahun 2019 tentang Penyakit Akibat Kerja;

d. Peraturan Presiden Nomor 34 Tahun 2014 tentang Pengesahan Convention Concerning The Promotional Framework for Occupational Safety and Health/Convention 187, 2006 (Konvensi Mengenai Kerangka 
Kerja Peningkatan Keselamatan dan Kesehatan Kerja/Konvensi 187,2006);

e. Peraturan Menteri Ketenagakerjaan Nomor 5 Tahun 2018 tentang Keselamatan dan Kesehatan Kerja Lingkungan Kerja;

f. Peraturan Menteri Ketenagakerjaan Nomor 18 Tahun 2016 tentang Dewan Keselamatan dan Kesehatan Kerja;

g. Peraturan Menteri Kesehatan Nomor 48 Tahun 2016 tentang Standar Keselamatan dan Kesehatan Kerja di Perkantoran;

h. Peraturan Menteri Kesehatan Nomor 56 Tahun 2016 tentang Penyelenggaraan Pelayanan Penyakit Akibat Kerja;

i. Peraturan Menteri Kesehatan Nomor 66 Tahun 2016 tentang Keselamatan dan Kesehatan Kerja Rumah Sakit; dan

j. Peraturan Menteri Kesehatan Nomor 70 Tahun 2016 tentang Persyaratan Kesehatan Lingkungan Kerja Industri.

Selain peraturan tersebut, masih terdapat beberapa peraturan teknis lainnya tekait dengan K3 yang sifat pengaturannya sektoral sesuai dengan jenis pekerjaan masing-masing. Pengaturan pada jenis ini lebih spesifik mengingat setiap sektor atau bidang pekerjaan mempunyai kebutuhan dan standar K3 yang bebeda-beda. Sebagai contoh peraturan K3 yang bersifat sektoral antara lain:

a. Peraturan Menteri Ketenagakerjaan Kerja Nomor 6 Tahun 2017 tentang Keselamatan dan Kesehatan Kerja Elevator dan Eskalator;

b. Peraturan Menteri Ketenagakerjaan Kerja Nomor 38 Tahun 2016 tentang Keselamatan dan Kesehatan Kerja Pesawat Tenaga dan Produksi;

c. Peraturan Menteri Ketenagakerjaan Nomor 33 Tahun 2015 tentang Perubahan Atas
Peraturan Menteri Ketenagakerjaan Nomor 12 Tahun 2015 tentang Keselamatan dan Kesehatan Kerja Listrik di Tempat Kerja; dan

d. Peraturan Menteri Ketenagakerjaan Nomor 31 Tahun 2015 tentang Perubahan Atas Peraturan Menteri Tenaga Kerja Nomor Per.02/men/1989 tentang Pengawasan jalur Instalasi Penyalur Petir.

Apabila melakukan penelusuran lebih lanjut tentang peraturan menteri terkait dengan K3 akan ditemukan lebih banyak lagi. Penelusuran ini dapat dilakukan melalui website jaringan dokumentasi dan informasi hukum (JDIH) pada Kementerian Ketenagakerjaan dan Kementerian Kesehatan. Berbagai peraturan tersebut menunjukkan bahwa sistem peraturan perudang-undangan di Indonesia telah memiliki banyak pengaturan terkait dengan $\mathrm{K} 3$.

\section{Kerangka Hukum Pengaturan K3 dan PPI pada Rumah Sakit}

Peraturan perundang-undangan di Indonesia telah mewajibkan setiap pengelola tempat kerja/perusahaan menerapkan K3. Pengaturan teknis K3 rumah sakit (K3RS) telah diatur dalam Permenkes K3RS. Penerapan K3 juga menjadi kewajiban bagi pengelola rumah sakit. Bahkan apabila mempertimbangkan karakteristik sektor pada rumah sakit maka penerapan K3 wajib diterapkan secara ketat dan teliti. Rumah sakit merupakan industri jasa yang melibatkan pekerja sangat banyak (labour intensive), padat modal dan padat teknologi sehingga risiko terjadinya Penyakit Akibat Kerja (PAK) dan Kecelakaan Akibat Kerja (KAK) sangat tinggi, oleh karena itu upaya K3 sudah menjadi suatu keharusan. ${ }^{17}$ Karakteristik lainnya dalam pelayanan rumah sakit adalah sifat pelaksanaan pekerjaannya yang terus menerus selama 24

Rejeki, Op.Cit., hal. 160. 
jam dan akses masuknya orang di luar pekerja ke dalam area tempat kerja seperti pasien, pendamping pasien dan pengunjung. Hal ini menyebabkan risiko pekerja rumah sakit terhadap PAK dan KAK semakin tinggi. Dalam lampiran Permenkes K3RS dijelaskan tiga hal yang mendasari semakin tingginya kebutuhan terhadap penyelenggaraan K3 Rumah Sakit (K3RS), yaitu: ${ }^{18}$

a. tuntutan terhadap mutu pelayanan Rumah Sakit semakin meningkat, sejalan dengan tuntutan masyarakat mendapatkan pelayanan kesehatan yang terbaik.

b. Rumah Sakit mempunyai karakteristik khusus antara lain banyak menyerap tenaga kerja (labor intensive), padat modal, padat teknologi, padat pakar, bidang pekerjaan dengan tingkat keterlibatan manusia yang tinggi dan terbukanya akses bagi bukan pekerja Rumah Sakit (pasien, pengantar dan pengunjung), serta kegiatan yang terus menerus setiap hari.

c. SDM Rumah Sakit, pasien, pendamping pasien, pengunjung, maupun lingkungan Rumah Sakit harus mendapatkan perlindungan dari gangguan kesehatan dan kecelakaan, baik sebagai dampak proses kegiatan pemberian pelayanan maupun karena kondisi sarana dan prasarana yang ada di Rumah Sakit yang tidak memenuhi standar.

Jenis pelayanan atau kegiatan yang dilakukan di rumah sakit juga memiliki bahaya yang sifatnya potensial di Rumah Sakit. Bahaya-bahaya potensial di rumah sakit dapat mengakibatkan terjadinya penyakit atau kecelakaan akibat kerja. bahaya potensial tersebut disebabkan oleh (i) faktor biologi seperti virus, bakteri, jamur, parasit; (ii) faktor kimia seperti antiseptik, reagent, gas anestesi; (iii) faktor ergonomi seperti lingkungan kerja, cara kerja, dan posisi kerja yang salah; (iv) faktor fisik seperti suhu, cahaya, bising, listrik, getaran dan radiasi; dan (v) faktor psikososial seperti kerja bergilir, beban kerja, penerimaan pasien gawat darurat, bangsal penyakit jiwa, dan ketegangan di kamar bedah. Sementara itu, pengelompokan bahaya potensial berdasarkan lokasi dan pekerjaan di rumah sakit antara lain: ${ }^{19}$

Tabel 1. Pengelompokan Bahaya Potensi Berdasarkan Lokasi dan Pekerjaan di Rumah Sakit

\begin{tabular}{|c|c|c|c|}
\hline No. & Bahaya Potensial & Lokasi & Pekerja yang paling berisiko \\
\hline \multirow[t]{5}{*}{1.} & \multicolumn{3}{|l|}{ Fisik } \\
\hline & Bising & $\begin{array}{l}\text { IPS-RS, laundry, dapur, CSSF, gedung } \\
\text { genset-boiler, IPAL }\end{array}$ & Karyawan yang bekerja di lokasi tersebut \\
\hline & Getaran & $\begin{array}{l}\text { ruang mesinmesin dan perlatan yang } \\
\text { menghasilkan getaran (ruang gigi dan } \\
\text { lain-lain) }\end{array}$ & perawat, cleaning service dan lain-lain \\
\hline & Debu & $\begin{array}{l}\text { genset, bengkel kerja, laboratorium gigi, } \\
\text { gudang rekam medis, incinerator }\end{array}$ & $\begin{array}{l}\text { Petugas sanitasi, teknisi gigi, petugas } \\
\text { IPS dan rekam medis }\end{array}$ \\
\hline & Panas & CSSD, dapur, laundri, incinerator, boiler & $\begin{array}{l}\text { pekerja dapur, pekerja laundry,petugas } \\
\text { sanitasi dan IP-RS }\end{array}$ \\
\hline
\end{tabular}

18 Lampiran Peraturan Menteri Kesehatan Republik Indonesia Nomor66 Tahun 2016 tentang Keselamatan dan Kesehatan Kerja.

19 Ibid 


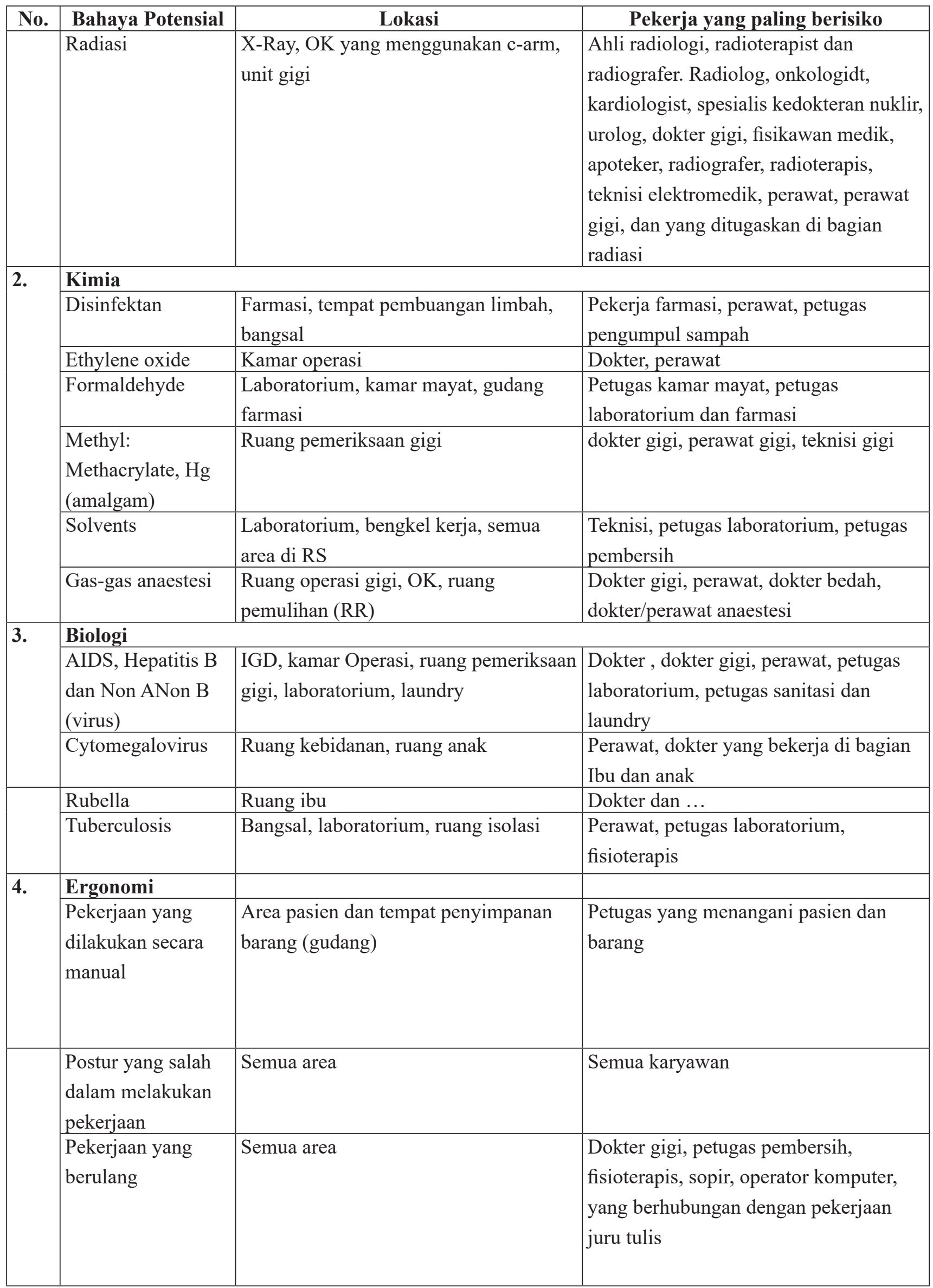




\begin{tabular}{|c|c|c|c|}
\hline No. & Bahaya Potensial & Lokasi & Pekerja yang paling berisiko \\
\hline \multirow[t]{2}{*}{5.} & \multicolumn{3}{|l|}{ Psikososial } \\
\hline & $\begin{array}{l}\text { Sering kontak } \\
\text { dengan pasien, } \\
\text { kerja bergilir, kerja } \\
\text { berlebih, ancaman } \\
\text { secara fisik }\end{array}$ & Semua area & Semua karyawan \\
\hline \multirow[t]{2}{*}{6.} & \multicolumn{3}{|l|}{ Mekanikal } \\
\hline & $\begin{array}{l}\text { terjepit mesin, } \\
\text { tergulung, } \\
\text { terpotong, tersayat, } \\
\text { tertusuk }\end{array}$ & $\begin{array}{l}\text { Semua area yang terdapat peralatan } \\
\text { mekanikal }\end{array}$ & Semua karyawan \\
\hline \multirow[t]{2}{*}{7.} & \multicolumn{3}{|l|}{ Elektrikal } \\
\hline & $\begin{array}{l}\text { Tersetrum, } \\
\text { terbakar, ledakan. }\end{array}$ & $\begin{array}{l}\text { Semua area yang terdapat arus atau } \\
\text { instalasi listrik }\end{array}$ & Semua karyawan \\
\hline \multirow[t]{2}{*}{8.} & \multicolumn{3}{|l|}{\begin{tabular}{|l|} 
Limbah \\
\end{tabular}} \\
\hline & $\begin{array}{l}\text { Tertumpah, } \\
\text { tertelan, terciprat, } \\
\text { terhirup, tertusuk }\end{array}$ & $\begin{array}{l}\text { Semua area yang menggunakan } \\
\text { menghasilkan limbah padat, limbah cair } \\
\text { dan limbah gas, limbah }\end{array}$ & Semua karyawan \\
\hline
\end{tabular}

Bahaya potensial yang terdapat di rumah sakit menyebar di sejumlah bagian atau area rumah sakit. Potensi bahaya, lokasi dan subyek yang memiliki risiko paling tinggi bisa berkembang seiring dengan perkembangan pelayanan di rumah sakit, penambahan SDM, penggunaan teknologi dan sebagainya. Potensi bahaya tersebut terjadi terus menerus sesuai operasional rumah sakit. Sasaran utama K3RS adalah karyawan rumah sakit, akan tetapi sebaran potensi bahaya untuk jenis tertentu berisiko juga terkena kepada bukan karyawan yaitu pasien, pendamping pasien dan pengunjung. Apalagi untuk jenis potensi bahaya yang berasal dari faktor biologi, kimia dan limbah.

Untuk mewujudkan optimalisasi K3RS, Permenkes K3RS mengatur tentang organisasi dan penilaian pelaksanaan K3RS. Terkait dengan organisasi, Permenkes K3RS mengatur bahwa setiap rumah sakit membentuk atau menunjuk satu unit kerja fungsional yang mempunyai tanggung jawab menyelenggarakan K3RS. Unit ini dapat berbentuk komite tersendiri atau terintegrasi dengan komite lainnya dan/atau instalasi K3RS. Komite K3RS bertanggungjawab langsung kepada pimpinan tertinggi rumah sakit. Anggota komite terdiri atas semua jajaran Direksi dan/atau kepala/perwakilan setiap unit kerja, (Instalasi/Bagian/Staf Medik Fungsional). Selain itu dalam komite terdapat sekretaris. Apabila rumah sakit membentuk instalasi K3RS maka kepala instalasi tersebut bertanggung jawab kepada direktur teknis. Selain itu, rumah sakit juga dapat membentuk unit pelayanan kesehatan kerja tersendiri atau terintegrasi dengan unit layanan rawat jalanan yang sudah ada di rumah sakit. Unit ini ditujukan bagi SDM rumah sakit. Upaya lain yang dilakukan oleh rumah sakit adalah penilaian K3RS yang dapat dilakukan secara internal dan eksternal. Penilaian eksternal K3RS terintegrasi dengan akreditasi rumah sakit. Materi tentang organisasi dan penilaian K3RS yang terintegrasi dengan 
akreditasi menjadi strategi untuk menjaga agar penerapan K3RS dapat dilakukan secara optimal dan berkesinambungan untuk memberikan perlindungan bagi pekerja rumah sakit sebagai sasaran utama yang akan berdampak pada pasien, pendamping pasien dan pengunjuang rumah sakit.

Selain pengaturan terkait dengan K3RS, upaya yang berkaitan dengan penciptaan K3 di rumah sakit juga diatur dalam Permenkes PPI. Permenkes PPI ini khusus mengatur upaya pencegahan dan pengendalian infeksi di fasilitas pelayanan kesehatan, termasuk rumah sakit. Pencegahan dan pengendalian infeksi dimaksudkan sebagai untuk mencegah dan meminimalkan infeksi pada pasien, petugas, pengunjung dan masyarakat sekitar fasilitas layanan kesehatan yang meliputi rumah sakit, puskesmas, klinik, dan praktik mandiri tenaga kesehatan. Sumber infeksi dapat berasal dari masyarakat (Community Acquired Infection) atau dari rumah sakit (Healthcare-Associated Infections/HAls). Sebelumnya, penyakit infeksi yang didapat di rumah sakit disebut sebagai Infeksi Nosokomial (Hospital Acquired Infection). Penyebutannya berubah Infeksi Terkait Layanan Kesehatan atau "HAIs" (Healthcare-Associated Infections). Perubahan penyebutan ini mengacu bahwa kejadian infeksi tidak hanya berasal dari rumah sakit, tetapi juga dapat dari fasilitas pelayanan kesehatan lainnya. Tidak terbatas infeksi kepada pasien namun dapat juga kepada petugas kesehatan dan pengunjung yang tertular pada saat berada di dalam lingkungan fasilitas pelayanan kesehatan.

Setiap fasilitas layanan kesehatan harus melaksanakan upaya pencegahan dan pengendalian infeksi. Penyakit infeksi terkait dengan layanan kesehatan merupakan salah satu masalah bidang kesehatan dan berdampak secara langsung sebagai beban ekonomi negara. ${ }^{20}$ Kejadian HAls ini sebenarnya dapat dicegah apabila fasilitas pelayanan kesehatan secara konsisten melaksanakan program PPI. Program PPI yang telah diatur dalam Permenkes PPI meliputi kewaspadaan isolasi, penerapan PPI terkait pelayanan kesehatan (Health Care Associated Infections/HAls) berupa langkah yang harus dilakukan untuk mencegah terjadinya HAls (bundles), surveilans HAls, pendidikan dan pelatihan serta penggunaan anti mikroba yang bijak. Disamping itu, dilakukan monitoring melalui Infection Control Risk Assesment (ICRA), audit dan monitoring lainya secara berkala. Program PPI di Fasilitas Pelayanan Kesehatan memiliki tujuan untuk meningkatkan kualitas pelayanan di fasilitas pelayanan kesehatan, sehingga melindungi sumber daya manusia kesehatan, pasien dan masyarakat dari penyakit infeksi yang terkait pelayanan kesehatan. PPI di rumah sakit sangat penting karena menggambarkan mutu pelayanan rumah sakit juga untuk melindungi pasien, petugas, pengunjung dan keluarga dari resiko tertularnya infeksi. ${ }^{21}$

PPI dilakukan melalui kewaspadaan standar dan kewaspadaan transmisi. Kewaspadaan standar yaitu kewaspadaan yang utama, dirancang untuk diterapkan secara rutin dalam perawatan seluruh pasien di rumah sakit dan fasilitas pelayanan kesehatan lainnya, baik yang telah didiagnosis, diduga terinfeksi atau kolonisasi. Diterapkan untuk mencegah transmisi silang sebelum pasien di diagnosis,

21 Mike Rismayanti dan Hardisman, Laporan Kasus Gambaran Pelaksanaan Program Pencegahan dan Pengendalian Infeksi di Rumah sakit Umum X Kota Y, Jurnal Kesehatan Andalas, 2019. ${ }^{20}$ Lampiran I Peraturan Menteri Kesehatan Nomor 7 Tahun 2017 tentang Pedoman Pencegahan dan Pengendalian Infeksi di Fasilitas Pelayanan Kesehatan. 
sebelum adanya hasil pemeriksaan laboratorium dan setelah pasien didiagnosis. Terdapat 11 komponen utama yang harus dilaksanakan dan dipatuhi dalam kewaspadaan standar, yaitu kebersihan tangan, Alat Pelindung Diri (APD), dekontaminasi peralatan perawatan pasien, kesehatan lingkungan, pengelolaan limbah, penatalaksanaan linen, perlindungan kesehatan petugas, penempatan pasien, hygiene respirasi/ etika batuk dan bersin, praktik menyuntik yang aman dan praktik lumbal pungsi yang aman. ${ }^{22}$

Pelaksanaan program PPI ini juga mengharuskan rumah sakit membentuk sebuah komite atau tim PPI. Komite atau tim PPI ini merupakan organisasi nonstruktural pada Fasilitas Pelayanan Kesehatan yang mempunyai fungsi utama menjalankan PPI serta menyusun kebijakan pencegahan dan pengendalian infeksi termasuk pencegahan infeksi yang bersumber dari masyarakat berupa tuberkulosis, HIV (Human Immunodeficiency Virus), dan infeksi menular lainnya. Dalam struktur organisasi rumah sakit, komite/tim PPI ini berada langsung di bawah pimpinan tertinggi atau direktur utama rumah sakit. Di dalam komite tersebut akan terdapat Ketua Komite, Sekretaris, Infection Prevention and Control Doctor (IPCD), Infection Prevention and Control Nurse (IPCN), Infection Prevention and Control Link Nurse (IPCLN) dan anggota lainnya yang terdiri: ${ }^{23}$
a. Tim DOTS
b. Tim HIV
c. Laboratorium.
d. Farmasi
e. Sterilisasi
f. Laundri

g. Instalasi Pemeliharaan Sarana Rumah Sakit (IPSRS).

h. Sanitasi lingkungan

i. pengelola makanan

j. Kesehatan dan Keselamatan Kerja (K3).

k. Kamar jenazah.

Komposisi pelaksana PPI di rumah sakit melibatkan setiap bagian yang terdapat dalam fungsi pelayanan di rumah sakit. Ini menunjukkan bahwa upaya perlindungan pekerja dan masyarakat yang berada di rumah sakit memiliki prioritas yang sangat tinggi. Pelaksanaan program PPI sangat penting dan menjadi keharusan diterapkan di rumah sakit. Program ini melengkapi K3RS yang berupaya mewujudkan keselamatan dan kesehatan bagi pekerja, masyarakat dan lingkungan di sekitar rumah sakit. Dalam organisasi rumah sakit bisa disimpulkan ada dua unit kerja yaitu Komite K3RS dan Komite/tim PPI. Keberadaannya diitujukan untuk memberikan perlindungan kerja secara optimal dengan sasaran utama pekerja dan sasaran lainnya adalah masyarakat.

\section{Perlindungan Tenaga Medis dan Kesehatan dalam Masa Pandemi}

Pada masa pandemi seperti COVID-19 saat ini kondisi rumah sakit berada pada risiko tinggi terhadap kejadian kecelakaan akibat kerja dan penyakit akibat kerja. Kondisi seperti ini diprediksikan masih akan berlangsung dalam beberapa waktu ke depan sampai ditemukannya vaksin untuk mengatasi COVID-19. Hal ini berarti selama masa pandemi dan sampai ditemukannya vaksin COVID-19 maka pekerja/karyawan di rumah sakit masih berada dalam risiko yang sangat tinggi akan terjadinya PAK dan KAK akibat

22 Lampiran I Peraturan Menteri Kesehatan Nomor 7 Tahun 2017 tentang Pedoman Pencegahan dan Pengendalian Infeksi di Fasilitas Pelayanan Kesehatan.

23 Lampiran I Peraturan Menteri Kesehatan Nomor 7 Tahun 2017 tentang Pedoman Pencegahan dan Pengendalian Infeksi di Fasilitas Pelayanan Kesehatan. 
COVID-19. Kewaspadaan terkait K3RS dan PPI pada masa pandemi meningkat dibanding pada situasi normal. Selain itu ketersediaan alat pelindung diri dan peralatan penunjang lainnya juga harus menjadi perhatian utama.

Hingga kini masih terdapat kejadian tenaga medis dan kesehatan yang terpapar COVID-19 bahkan beberapa kejadian mengakibatkan meninggal dunia. Kejadian ini menjadi tantangan besar di tengah masih terjadinya pandemi COVID-19 mengingat tenaga medis dan kesehatan menjadi unsur utama dan terdepan dalam melakukan penanganan COVID-19. Sejumlah undang-undang telah mengatur tentang jaminan perlindungan terhadap tenaga medis dan kesehatan pada saat menjalankan tugasnya dalam kondisi normal maupun dalam konidisi darurat. Ketentuan tersebut meliputi:

\section{a. Pemberian Penghargaan}

Petugas yang melaksanakan upaya penanggulangan wabah dapat diberikan penghargaan atas risiko dalam menjalankan tugasnya tersebut. Yang dimaksud wabah adalah kejadian berjangkitnya suatu penyakit menular dalam masyarakat yang jumlah penderitanya meningkat secara nyata melebihi dari pada keadaan yang lazim pada waktu dan daerah tertentu serta dapat menimbulkan malapetaka. Penghargaan yang dapat diberikan kepada petugas dapat berupa uang atau bentuk lainnya. Ketentuan ini terdapat di dalam UndangUndang Nomor 4 Tahun 1984 tentang Wabah Penyakit Menular dan peraturan turunannya yaitu Peraturan Pemerintah Nomor 40 Tahun 1991 tentang Penanggulangan Wabah Penyakit Menular.

\section{b. Perlindungan Atas K3}

Tenaga kesehatan dalam menjalankan praktiknya berhak memperoleh perlindungan atas keselamatan dan kesehatan kerja,
Ketentuan ini terdapat dalam Pasal 57 UndangUndang Nomor 36 Tahun 2014 tentang Tenaga Kesehatan. Ketentuan ini juga sejalan dengan ketentuan yang terdapat dalam UU Ketenagakerjaan yang mengatur hak normative pekerja untuk mendapatkan perlindungan atas K3. Dalam rumusan pasalnya baik UU Tenaga Kesehatan maupun UU ketenagakerjaan juga menambahkan perlindungan untuk memperoleh perlakuan yang sesuai dengan harkat dan martabat manusia, moral, kesusilaan, serta nilai-nilai agama.

\section{c. Pendayagunaan Tenaga Kesehatan}

Dalam penyelenggaraan upaya penanggulangan penyakit menular terdapat tahapan pembinaan yang merupakan kewenangan pemerintah dan pemerintah daerah. salah satu upaya pembinaan dilakukan melalui pendayagunaan tenaga kesehatan. Hal ini diatur dalam Peraturan Menteri Kesehatan Nomor 84 Tahun 2014 tentang Penanggulangan Penyakit Menular. Pasal 41 ayat (3) Peraturan Menteri tersebut mengatur bahwa pendayagunaan tenaga kesehatan dalam kaitan pembinaan penyelenggaraan penanggulangan penyakit menular dapat dilakukan melalui:

- pendidikan dan pelatihan teknis;

- pemberian penghargaan; dan/atau

- promosi jabatan.

Jadi dalam kaitan pembinaan ini maka terdapat tiga jenis manfaat atau aktifitas pembinaan yang bisa diterima oleh tenaga kesehatan. Namun, ketentuan lebih teknis mengenai hal ini tidak terdapat dalam peraturan tersebut.

\section{d. Jaminan Kecelakaan Kerja}

Tenaga kesehatan sebagai bagian dari pekerja juga berhak mendapatkan jaminan kecelakaan kerja apabila mengalami kejadian kecelakaan akibat kerja atau penyakit akibat 
kerja. Pengaturan hak jaminan kecelakaan kerja ini dalam kerangka sistem jaminan sosial nasional yang diatur dalam Undang-Undang Nomor 40 Tahun 2004 tentang Sistem Jaminan Sosial Nasional. Tenaga kesehatan akan mendapatkan manfaat jaminan kecelakaan kerja ini apabila menjadi peserta dalam BPJS Ketenagakerjaan. tempat lain yang ditetapkan untuk menanganai pasien terinfeksi Covid-19, dan relawan sebagai pekerja/buruh dan/atau tenaga kerja yang dapat dikategorikan memiliki risiko khusus/ spesifik yang dapat mengakibatkan PAK karena Covid-19. pengelompokan pekerja dapat dilihat pada tabel di bawah ini:

Tabel 2: Pengelompokan Pekerja yang Dikategorikan Memiliki Risiko PAK Karena COVID-19

\begin{tabular}{|c|c|}
\hline $\begin{array}{l}\text { Tenaga medis dan tenaga } \\
\text { kesehatan }\end{array}$ & $\begin{array}{l}\text { 1. Dokter, dokter gigi, dokter spesialis dan dokter gigi spesialis; } \\
\text { 2. Tenaga keperawatan; } \\
\text { 3. Tenaga kebidanan; } \\
\text { 4. Tenaga teknnik biomedika seperti ahli teknologi laboratorium } \\
\text { medik; } \\
\text { 5. Tenaga kefarmasian seperti apoteker dan tenaga teknis kefarmasian; } \\
\text { dan } \\
\text { 6. Tenaga kesehatan masyarakat sepeerti epidemiolog kesehatan. }\end{array}$ \\
\hline $\begin{array}{l}\text { Tenaga pendukung kesehatan } \\
\text { pada rumah sakit, fasilitas } \\
\text { kesehatan dan/atau tempat lain } \\
\text { yang ditetapkan untuk menanganai } \\
\text { pasien terinfeksi Covid-19 }\end{array}$ & $\begin{array}{l}\text { Cleaning service, pekerja laundry, dan pekerja lainnya yang dalam } \\
\text { pekerjaannya menghadapi risiko tertular/terpapar COVID-19 di } \\
\text { lingkungan kerjanya tersebut. }\end{array}$ \\
\hline Tim relawan & $\begin{array}{l}\text { Tenaga kesehtan dan non kesehatan yang turut bertugas dalam } \\
\text { penanggulangan COVID-19 yang dapat ditempatkan langsung di rumah } \\
\text { sakit, fasilitas kesehatan, dan/atau tempat lain yang ditetapkan dalam } \\
\text { penanggulangan COVID-19. }\end{array}$ \\
\hline
\end{tabular}

Pada masa pandemik ini, perlindungan jaminan kecelakaan kerja telah dijelaskan oleh Menteri Ketenagakerjaan melalui Surat Edaran Menteri Ketenagakerjaan Nomor M/8/HK.04/V/2020 tentang Perlindungan Pekerja/Buruh Dalam Program Jaminan Kecelakaan Kerja Pada Kasus Penyakit Akibat Kerja Karena Corona Virus Disease 2019 (COVID-19). Dalam Surat Edaran tersebut Covid-19 dapat dikategorikan PAK dalam klasifikasi penyakit yang disebabkan pajanan faktor yang timbul dari aktifitas pekerjaan yaitu kelompok faktor pajanan biologi. Surat Edaran ini memasukkan tenaga media dan tenaga kesehatan, tenaga pendukung kesehatan pada rumah sakit, fasilitas kesehatan dan/atau
Selanjutnya, Menteri Ketenagakerjaan meminta kepada Gubernur melakukan sejumlah hal yaitu: pertama, memastikan perusahaan/ organisasi yang mempekerjakan pekerja/buruh yang berisiko terkena PAK karena COVID-19 mendaftakan pekerjanya ke dalam program jaminan sosial pada BPJS Ketenagakerjaan. Kedua, memastikan pekerja yang disebutkan dalam Surat Edaran tersebutyang mengalami PAK mendapatkan hak manfaat jaminan kecelakaan kerja sesuai peraturan perundang-undangan. Ketiga, apabila perusahaan/organisasi belum mendaftarkan pekernya dalam program jaminan kecelakaan kerja BPJS Ketenagakerjaan maka apabila pekerjanya terkena PAK karena 
COVID-19, perusahaan/organisasi memberikan hak manfaat program jaminan kecelakaan kerja sesuai ketentuan peraturan perundangundangan.

Uraian di atas menjelaskan ada empat jenis perlindungan yang diberikan kepada tenaga kesehatan dan tenaga medis pada saat terjadinya pademi seperti COVID-19. Perlindungan tersebut sudah diatur di dalam peraturan perundangundangan, namun terdapat jenis perlindungan yang rincian pelaksanaannya belum diatur secara jelas yaitu bentuk pemberian penghargaan yang diatur dalam Undang-Undang Nomor 4 Tahun 1984 tentang Wabah Penyakit Menular yang diatur di dalam Permenkes Nomor 84 Tahun 2014 tentang Penanggulangan Penyakit Menular. Ketiadaan pengaturan teknis ini menimbulkan ketidakpastian pemenuhan hak bagi tenaga kesehatan dan tenaga medis yang telah diatur dalam peraturan perundangundangan. ${ }^{24}$ Bentuk lain dari jaminan perlindungan terkait dengan jaminan kecelakaan kerja. Namun, jaminan ini dimasukkan dalam kerangka jaminan sosial nasional dalam bentuk BPJS Ketenagakerjaan. Untuk mendapatkan manfaat jaminan kecelakaan kerja maka tenaga kesehatan atau tenaga media yang terkena PAK karena COVID-19 harus telah terdaftar dalam BPJS Ketenagakerjaan. Apabila belum terdaftar, maka kewajiban pemberian manfaat jaminan kecelakaan kerja terletak pada perusahaan/ organisasi sebagai pemberi kerja. Dari ketiadaan pengaturan yang jelas tentang pemberian penghargaan dan pendayagunaan tenaga kesehatan serta dibebankannya penggantian akibat terkena PAK COVID-19 dalam kerangka BPJS Ketenagakerjaan dan yang ditanggung oleh pemberi kerja menunjukkan masih minimnya penghargaan dari negara sebgaa bentuk penghormatan atau penggantian/kompensasi kerugian atas kejadian PAK karena COVID-19 bagi pekerja yang menjalankan tugas penanganan pandemi COVID-19.

\section{Penutup}

K3 merupakan aspek penting dalam pelaksanaan hubungan kerja yang telah diatur dalam peraturan perundang-undangan sebagai salah satu jenis hak normatif pekerja/buruh. Pemenuhan K3 merupakan tanggung jawab atau kewajiban pemberi kerja atau perusahaan. sebagai upaya pencegahan terjadinya KAK dan PAK. Pelaksanaan K3 diupayakan untuk kondisi lingkungan kerja yang sehat bagi pekerja sehingga memberikan pengaruh positif bagi produktifitas pekerja. Pengaturan tentang kesehatan kerja dalam peraturan perundangundangan di Indonesia diberlakukan bagi pekerjaan sektor formal maupun pekerjaan sektor non-formal. Pada masa pandemi seperti COVID-19 penerapan K3 perlu mendapatkan perhatian yang serius dari perusahaan atau pemberi kerja. Rumah sakit sebagai salah satu bentuk lingkugan kerja memiliki karakteristik khusus yang menempatkan pada situasi risiko

24 Meskipun dalam prakteknya, pemerintah telah memberkan insentif bagi tenaga kesehatan yang menjalankan tugas penanganam COVID-19. Sebagai contoh Pemerintah DKI Jakarta melalui Peraturan Gubernur DKI Jakarta No. 23 Tahun 2020 tentang Pemberian Insentif Kepada Tenaga Kesehatan dan Tenaga Penunjang Kesehatan dalam Penanggulangan Bencana Wabah Corona Virus Disease 2019. Insentif tersebut berupa (i) uang transportasi dan (ii) uang makan dan uang snack. Namun, apabila dilihat dari segi istilah maka terdapat perbedaaan antara insentif dengan penghargaan. Insentif dalam Kamus Besar Bahasa Indonesia adalah tambahan penghasilan (uang, barang, dan sebagainya) yang diberikan untuk meningkatkan gairah kerja. Sementara penghargaan adalah sesuatu atau hal dan sebagainya menghargai; penghormatan. Perbedaan ini menunjukkan bahwa insentif ini bukan merupakan bentuk penghargaan bagi tenaga kesehatan atau tenaga medis. Selain dari sisi istilah, dasar hukum penetapan insentif tersebut juga bukan bersumber dari peraturan perundang-undangan yang mengatur tentang penghargaan dan pendayagunaan tenaga kesehatan. 
tinggi terjadinya PAK akibat COVID-19. Untuk menciptakan lingkungan kerja yang sehat dan melindungi pekerja dari paparan risiko potensi bahaya di rumah sakit telah diatur penerapan K3RS dan program PPI. Penerapan K3RS dan program PPI mempunyai sasaran utama bagi pekerja/karyawan rumah sakit. Namun penerapannya juga berdampak pada pihak lain yang bukan merupakan karyawan rumah sakit yaitu pasien, pendamping pasien dan pengunjung rumah sakit. Pada situasi pandemi COVID-19 ini kinerja K3RS dan PPI menjadi unsur penting dalam memberikan perlindungan bagi pekerja/karyawan rumah sakit dan masyarakat.

Pada masa pandemi COVID-19, tenaga medis dan tenaga kesehatan memiliki peran utama dalam penanganan COVID-19. Posisi ini menempatkannya pada risiko tinggi terpapar COVID-19. Tingginya risiko pekerja/ karyawan rumah sakit terhadap PAK karena COVID-19 belum diimbangi dengan pengaturan terkait jaminan perlindungan kerja. Ada empat jenis perlindungan yang sudah diatur dalam peraturan perundang-undangan yaitu pemberian penghargaan, perlindungan atas K3, pendayagunaan tenaga kesehatan dan jaminan kecelakaan kerja. Dari empat perlindungan tersebut baru perindungan atas K3 yang diatur secara rinci dalam peraturan perundang-undangan. Dua bentuk perlindungan yaitu pemberian penghargaan dan pendayagunaan tenaga kesehatan belum ditemukan aturan yang menjamin implementasi perlindungannya. Sementara itu, jaminan kecelakaan kerja dimasukkan ke dalam skema BPJS Ketenagakerjaan dan akan menjadi beban perusahaan apabila belum terdaftar sebagai peserta BPJS Ketenagakerjaan.

Untuk mengoptimalkan perlindungan tenaga medis dan tenaga kesehatan pada masa pandemi dengan mempertimbangkan tugas penting yang harus dilakukan maka diperlukan pengawasan dan pendampingan oleh pemerintah terkait dengan pelaksanaan K3RS dan PPI di rumah sakit. Selain itu untuk memberikan ketenangan pelaksanaan kerja bagi karyawan rumah sakit yang melakukan penanganan COVID-19 perlu diatur skema yag lebih rinci terkait dengan jaminan pemberian penghargaan dan pendayagunaan tenaga kesehatan yang telah diatur dalam peraturan perundang-undangan. Bersamaan dengan pengaturan ini, pemerintah juga perlu merumuskan jaminan kecelakaan kerja bagi tenaga medis dan tenaga kesehatan yang terkena PAK melalui skema di luar program BPJS Ketenagakerjaan. Hal ini merupakan bentuk tanggung jawab pemerintah terhadap tenaga media dan tenaga kesehatan yang telah berjuang dalam melakukan penanganan pandemi COVID-19. 


\section{DAFTAR PUSTAKA}

\section{A. Buku}

Intenational Labour Organzation, Occupational Safety and Health Policy Document, On The Road to a Safer and Healthier Culture at Work, March 2016.

International Labour Organization-Office Jakarta, Keselamatan dan Kesehatan Kerja, Sarana untuk Produktifitas Kerja, (Jakarta: ILO, 2013).

Kementerian Kesehatan, Pedoman Kesiapsiagaan Menghadapi Infeksi Novel Coronavirus (2019-nCoV), Direktorat Jenderal Pencegahan dan pengendalian Penyakit, Januari 2020.

Kementerian Kesehatan, Pedoman Kesiapsiagaan Menghadapi Infeksi Novel Coronavirus (2019-nCoV), Direktorat Jenderal Pencegahan dan pengendalian Penyakit, Maret 2020.

Rejeki, Sri. Keselamatan dan Kesehatan Kerja, Pusat Pendidikan SDM Kesehatan, Badan Pengembangan dan Pemberdayaan SDM Kesehatan.

Sujoso, Anita Dewi Prahastuti. Dasar-dasar Keselamatand an Kesehatan Kerja, (Jember: Jember University Press, 2012).

\section{B. Jurnal}

Rismayanti, Mike dan Hardisman, "Laporan Kasus Gambaran Pelaksanaan Program Pencegahan dan Pengendalian Infeksi di Rumah sakit Umum X Kota Y", Jurnal Kesehatan Andalas, (2019).

\section{Internet}

Amalia Zharina, Kronologi Virus Corona di China Dari Pasar hingga Korea Selatan, https:// sains.kompas.com/read/2020/01/21/183300123/-kronologi-virus-corona-di-china-daripasar-hingga-korea-selatan?page=all, (diakses 7 Oktober 2020).

Azanella, Luthfia Ayu. 32 Dokter Meninggal Akibat COVID-19 Mayoritas Bertugas di RS Non Covid, dimuat dalam https://www.kompas.com/tren/read/2020/06/07/151200365/32dokter-meninggal-akibat-covid-19-mayoritas-bertugas-di-rs-non-covid-19, (diakses 14 Juni 2020_.

Baskara, Bima. Rangkaian Peristiwa Pertama COVID-19 dimuat dalam https://kompas.id/ baca/riset/2020/04/18/rangkaian-peristiwa-pertama-covid-19/ (diakses 13 Juni 2020_.

Joniansyah, Ini Empat Sungai di Kabupaten Tangerang Tercemar Limbah Industri, https:// metro.tempo.co/read/1187764/ini-4-sungai-di-kabupaten-tangerang-tercemar-limbahindustri/full\&view=ok, (diakses 7 Oktober 2020).

Kementerian Kesehatan, Situasi COVID-19,dimuat dalam https://www.kemkes.go.id/, (diakses 14 Juni 2020).

Mantalean, Vitoriao. PPNI:20 Perawat di Indonesia Meninggal Dunia dalamTugas Melayani Pasien COVID-19, dimuat dalam https://megapolitan.kompas.com/read/2020/05/19/05582081/ ppni-20-perawat-di-indonesia-meninggal-dunia-dalam-tugas-melayani-pasien, (diakses 15 Juni 2020).

\section{Peraturan Perundang-undangan}

Undang-Undang Nomor 1 Tahun 1970 tentang Keselamatan Kerja Undang-Undang Nomor 4 Tahun 1984 tentang Wabah Penyakit Menular 
Undang-Undang Nomor 13 Tahun 2003 tentang Ketenagakerjaan

Undang-Undang Nomor 40 Tahun 2004 tentang Sistem Jaminan Sosial Nasional

Undang-Undang Nomor 36 Tahun 2009 tentang Kesehatan

Undang-Undang Nomor 36 Tahun 2014 tentang Tenaga Kesehatan

Peraturan Pemerintah Nomor 40 Tahun 1991 tentang Penanggulangan Wabah Penyakit Menular.

Peraturan Menteri Kesehatan Nomor 84 Tahun 2014 tentang Penanggulangan Penyakit Menular

Peraturan Menteri Kesehatan Nomor 66 Tahun 2016 tentang Keselamatan dan Kesehatan Kerja Rumah Sakit

Peraturan Menteri Kesehatan Nomor 7 Tahun 2017 tentang Pedoman Pencegahan dan Pengendalian Infeksi di Fasilitas Pelayanan Kesehatan 


\section{BIODATA PENULIS}

M Nur Sholikin, S.H. saat ini menjadi peneliti Pusat Studi Hukum dan Kebijakan Indonesia (PSHK). Pernah menjabat sebagai Direktur Eksekutif PSHK periode 2015-2019. Memiliki pengalaman lebih dari 15 tahun dalam penelitian dan advokasi bidang hukum dengan fokus pada legislasi/peraturan perundang-undangan dan peradilan. Aktif menjadi narasumber dalam berbagai forum yang membahas masalah hukum. Memiliki pengalaman bekerja dengan lembaga pemerintah baik sebagai tim ahli, anggota Pokja, konsultan maupun narasumber. Selain itu, juga sebagai pengajar di Sekolah Tinggi Hukum Indonesia Jentera untuk mata kuliah IImu Perundang-undangan, Birokrasi dan Desentralisasi. Sejumlah gagasannya tentang perkembangan hukum ditulis dalam artikel dan dimuat di beberapa jurnal dan media nasional.

dr. Herawati, menyelesaikan pendidikan profesi pada Program Studi Kedokteran Umum Universitas Diponegoro pada 2004. Saat ini tercatat sebagai anggota Ikatan Dokter Indonesia (IDI) Cabang Tangerang Selatan dengan Surat Tanda Registrasi Dokter (STR) Konsil Kedokteran Indonesia (KKI). Memiliki beragam pengalaman praktik di beberapa rumah sakit, Puskesmas, dan klinik di beberapa kota seperti Semarang, Pemalang, Bekasi, Depok dan Jakarta. Sampai dengan saat ini memiliki ketertarikan mendalami ilmu pengetahuan di bidang kedokteran melalui forum ilmiah seperti pelatihan, seminar dan workshop. Karya ilmiahnya dimuat dalam Jurnal Media Medika Indonesiana dengan judul Kebugaran Jasmani pada Penderita Tonsilitis Kronis Dibanding Anak Normal (Usia 12-14 Tahun). 